\title{
Alcohol use disorders: a trans-cultural study among the Slavic and Arabian undergraduates in Belarus
}

\author{
Menizibeya Welcome*, Vladimir Pereverzev \\ From $1^{\text {st }}$ International Congress on Neurobiology and Clinical Psychopharmacology and European \\ Psychiatric Association Conference on Treatment Guidance \\ Thessaloniki, Greece. 19-22 November 2009
}

\section{Background}

The pattern of alcohol use might vary among people of different cultural backgrounds. Differences in alcohol use and related problems among undergraduates of various ethnic groups - Slavs, Arabians in Minsk, Belarus were analyzed.

\section{Materials and methods}

In a randomized anonymous study, we analyzed the results of 1345 Slavic, 120 Arabian undergraduates in Minsk, Belarus. All respondents were administered questionnaire containing the AUDIT, including other alcohol-related questions. The AUDIT cut-off point was set at 8 .

\section{Results}

Overall, 91.1\% Slavic, 63.3\% Arabian undergraduates were alcohol users. A total of 16.3\% Slavic, 32.5\% Arabian problem drinkers were identified. Generally, beer was the most preferred alcoholic beverage among the undergraduates of both the Slavic and Arabian population.

\section{Conclusions}

Differences in the pattern of alcohol use and related problems exist among various ethnicities - Slavs and Arabs in Belarus. The Slavs had higher percentages of alcohol users, but relatively lower proportion of problem drinkers, compared to the results of the Arabs. Higher AUDIT scores were recorded for the Arabs. No significant differences were noted in the preference for alcoholic beverages among all ethnicities.

Department of Human Physiology, Belarusian State Medical University, Minsk, Belarus
Published: 22 April 2010

doi:10.1186/1744-859X-9-S1-S212

Cite this article as: Welcome and Pereverzev: Alcohol use disorders: a trans-cultural study among the Slavic and Arabian undergraduates in Belarus. Annals of General Psychiatry 2010 9(Suppl 1):S212.
Submit your next manuscript to BioMed Central and take full advantage of:

- Convenient online submission

- Thorough peer review

- No space constraints or color figure charges

- Immediate publication on acceptance

- Inclusion in PubMled, CAS, Scopus and Google Scholar

- Research which is freely available for redistribution

Submit your manuscript at www.biomedcentral.com/submit
C Biomed Central 